\title{
Preferential Transfers and the Value of the Insolvent Firm
}

Section 60 of the Bankruptcy Act provides that transfers of assets or security interests ${ }^{1}$ by the bankrupt on account of antecedent debts, made within four months of the petition in bankruptcy and while the bankrupt was insolvent," are "preferences" and may be avoided by the trustee if he proves that the creditors receiving them had reasonable cause to believe that the debtor was insolvent at the time of the transfer. ${ }^{3}$ The Bankruptcy Act revision now before Congress (H.R. 8200) reduces the preference period to three months, but eliminates the "reasonable cause to believe" requirement and shifts the burden of going forward on the question of insolvency to the transferee. ${ }^{4}$

The most obvious function of preference law is to enrich the estate by recovering moneys paid to creditors in the months before the filing

1. Bankruptcy Act $\$ 1(30)$, 11 U.S.C. $\$ 1(30)$ (1970) "“transfer" broadly defined).

2. A firm is insolvent in the "bankruptcy" or "balance-sheet" sense if it has assets at fair valuation insufficient to pay its debts. Id. $\S 1(19)$, I1 U.S.C. $\S 1(19)(1970)$.

3. Id. $\$ 60(a)$, (b), 11 U.S.C. $\$ 96(a)$, (b) (1970). To be a preference, a transfer must also give the transferee a "greater percentage of his debt than some other creditor of the same class." Id. $\$ 60(a), 11$ U.S.C. $\$ 96(a)$ (1970). The "classes" referred to are defined by id. $\$ 64(a), 11$ U.S.C. $\$ 104(a)$ (1970), which grants priorities for wages, taxes, and certain rents. See 3 J. Moore \& L. King, Collier on Bankruptcy 60.34 , at 904 (14th ed. 1977). As a practical matter, the "greater percentage" requirement encompasses virtually all payments to ordinary creditors during insolvency, see id. $\uparrow 60.34$. In addition to the provisions of $\$ 60, \$ 67$ (a) makes judicial liens obtained within the four-month period during the debtor's insolvency voidable without regard to the transferee's knowledge.

These provisions account for most of American preference law. Preferences were valid at common law, $3 \mathrm{~J}$. Moore \& L. KING, supra 60.02 , at 755 , and the few state statutes that remain, e.g., OHo REv. CodE ANN. $\$ 1313.56$ (Page 1962), are considered ineffective, Seligson, Preferences Under the Bankrupicy Act, 15 VAND. L. REv. 115, 116 (1961).

4. H.R. 8200, 95th Cong., 2d Sess. $\$ 547(\mathrm{~b})$, (f) (1978), passed by House, 95th Cong., $2 \mathrm{~d}$ Sess., 124 Conc. Rec. H478 (daily ed. Feb. 1, 1978); S. 2266, 95th Cong., lst Sess. $\$ 547(b)$, (f) (1977) [bills with substantially identical preference provisions, hereinafter cited without cross reference to H.R, 8200 only]. See REPORT OF THE COMmission ON THE BANkRuptcy Laws of the United States, H.R. Doc. No. 137, 93d Cong., Ist Sess., pt. I, at 201-02 (1973) [hereinafter cited as Commission REPORT]. H.R. 8200 would also make transfers to insiders vulnerable for an additional nine months subject to the scienter and burden-of-proof requirements of existing law. H.R. $8200 \$ 547(b)$. The term "insider" encompasses the transferor's officers and directors and their families. Id. $\S 101(24)$.

Section 547 (c) exempts from preference attack exchanges with the debtor for substantially contemporaneous new value, id. $\$ \S 547(c)(1),(3),(4)$, and payments in the ordinary course of business made within 45 days after the debt was incurred, id. $\$ 547$ (c)(2). Section 547 (c) also adopts a new test for determining the extent to which fluctuations in the value of inventory or receivables covered by a perfected security interest may amount to preferential transfers, id. $\$ 547(\mathrm{c})(5)$. 
of the petition. ${ }^{5}$ These sums can then be redistributed among the creditors according to the priority rules of the $\mathrm{Act}^{\mathrm{b}}$ and the rule of equality among creditors of the same class. ${ }^{7}$ But preference law has another, less obvious and less discussed function: the control of creditor behavior during insolvency. ${ }^{8}$ By determining whether a transfer will be valid in bankruptcy, section 60 influences the decision to seek a transfer. The importance of controlling this decision extends beyond this goal of maintaining equality ${ }^{9}$ because the ultimate fate of the firm-and hence its total value-depends in part on the attitudes and actions of its creditors. ${ }^{10}$ The second goal of preference law should be to maximize the firm's total value by influencing creditor responses to the firm's situation.11

This Note argues that the value of the firm can be maximized only if creditor equality is strictly maintained. Part I shows how individual creditors, in the absence of an effective preference law, may seek individual gain at the expense of the firm and of the creditor group as a whole. Part II examines existing preference law and the preference provisions of H.R. 8200 and concludes that both fail to control the destructive tendencies described in Part I. Part III then proposes a preference statute that reduces the existing incentives that now frustrate the maximization goal by rewarding selfish behavior. The proposed

5. Seligson, supra note 3, at 115 ("[T]he Bankruptcy Act provides the trustee with an arsenal of weapons to enable him to bring into the estate for distribution property which in equity and good conscience should be available to all. The power to avoid preferential transfers is one of these weapons."); Bankruplcy Act Revision: Hearings on H.R. 31 and H.R. 32 Before the Subcomm. on Civil and Constitutional Rights of the House Comm. on the Judiciary, 94th Cong., Ist \& 2d Sess., pt. 3, at 1840 (1975-1976) (Leon S. Forman, Nat'l Bankr. Conf.) [hereinafter cited as House Hearings].

6. Bankruptcy Act $\$ 64,11$ U.S.C. $\$ 104$ (1970).

7. $3 \mathrm{~J}$. MOORE \& L. KING, supra note $3,-60.01$, at 743 \& n.1; Seligson, supra note 3 , at 115. On the Bankruptcy Act's concept of "classes" of creditors, see note 3 supra.

8. J. Maclachlan, Handbook of the Law of Bankruptcy 284 (1956) ("[T]he most significant effect of the law of preferences is not the value of the assets recovered in bankruptcy, but the weakening of the inducements to negotiate preferential arrangements with insolvent debtors."); Commission Reporx, supra note 4, pt. I, at 202.

9. Some analyses see deterrence only as a means of promoting equality. See Commission REPORT, supra note 4, pt. I, at 19.

10. Stierhoff, Insolvency doesn't have to mean bankruptcy, if . . ., Bankinc, August 1975 , at 84 . Creditor lawsuits are a major short-run factor precipitating voluntary petitions, Commission REPORT, supra note 4 , pt. I, at 49 , which in turn can lead to liquidation at a time when the firm's going-concern value is greater than its liquidation value, House Hearings, supra note 5, pt. 1, at 433, 434 (Peter F. Coogan, Esq.) [testimony hereinafter cited as Coogan Testimony].

11. The policy of equality does not distinguish between preferences deterred and preferences taken and then recovered, except with respect to the time-value of money or other transactions costs. The maximization goal, however, depends for its effectiveness on deterrence and therefore requires that creditors be aware that obtaining preferences is futile in those situations in which their behavior is to be controlled. See p. 1467 \& note 78 infra. 
statute would realize both goals of preference law more fully than either section 60 or H.R. 8200 , without untoward effects on the administration of estates in bankruptcy or on initial decisions to lend.

\section{An Analysis of the Insolvency Situation}

When a firm is producing funds sufficient to meet its maturing obligations, bankruptcy law does not concern itself with how or when such a firm pays its debts. ${ }^{12}$ When the firm is unable to pay its debts and only some of its creditors can be paid on time, however, there is a threat to the principle of creditor equality, ${ }^{13}$ and the firm's transfers are subject to scrutiny. ${ }^{14}$ In these circumstances, the protection of creditors is an important policy goal. ${ }^{15}$ The maximization of the value of the insolvent firm for the benefit of the creditors thus should be one goal of bankruptcy policy. Yet even though the creditor class has great power over the firm's immediate future, that power may not be used to enhance the total value of the firm unless the equality principle is strictly enforced.

\section{A. The Creditors' Dilemma}

No problems of either equality or maximization arise when the firm's debt is owned by a single creditor. The sole creditor faces two options: support the firm in the hope of financial recovery and full repayment, or liquidate the firm and thereby realize as much of its debt as possible. The sole creditor can maximize its return only by max-

12. See G. Glenn, The Law Governing Liquidation $\$ 13$, at 22 (1935); J. Maclachlan, supra note 8 , at 10 .

13. Equality among creditors is a basic goal of bankruptcy law. $3 \mathrm{~J}$. MOore \& L. KING, supra note 3, 60.01, at 743; Commission RElokT, supra note 4, pt. I, at 76.79. In the absence of bankruptcy law or some other collective legal response to the debtor's insolvency, certain creditors, acting to exercise their individual remedies, must prevail over others in the "race of the diligent." G. GLeNs, supra note $12, \S 5$. This would defeat the equality goal. See 3 J. Moore \& L. KING, supra note 3, 60.01, at 744 .

14. The fraudulent conveyance action also scrutinizes such transfers. See, e.g., Bankruptcy Act $\$ 67$ (d), 11 U.S.C. $\$ 107$ (d) (1970); UNIForM FraUdulent Conveya.ice ACT.

15. G. Glens, supra note $12, \$ 3$. Protection of creditors from unequal treatment is a major policy of the Bankruptcy Act. In Chapter $\mathrm{X}$ reorganizations, the absolute priority rule decrees that junior claims cannot be recognized until senior claims are satisfied in full. Consolidated Rock Prods. Co. v. DuBois, 312 U.S. 510, 527-30 (1941); see Blum \& Kaplan, The Absolute Priorily Doctrine In Corporate Reorganizations, 41 U. CHI. L. REv. 651 (1974). Chapter XI arangements are to be "in the best interests of creditors." Bankruptcy Act $\$ 366(2)$, 11 U.S.C. $\$ 766(2)$ (1970) (emphasis added). Similarly, although owners might want to continue the business when their equity is under water but solvency might be regained, see J. MACLACHLAN, supra note 8 , at 2 , the owner's interest in straight bankruptcy is limited to discharge, see, e.g., id. at 16-17; Commission REPORT, supra note 4, pt. $I$, at $75,79-81$. 
imizing the value of the firm; ${ }^{16}$ the decisions of the sole creditor may therefore be considered the norm with which decisions made in the multicreditor case should coincide.

Most firms, of course, have many creditors who normally make decisions independently. To enable the creditors to coordinate their responses to the fate of their common debtor, the law provides a number of collective mechanisms that parallel the sole creditor's options of support and liquidation. Through a common law composition, some or all of the creditors can agree to extend the maturity of their debts, to scale them down, ${ }^{17}$ or even to subordinate some debts to others in the hope of preserving the firm's going-concern value. ${ }^{18}$ Alternatively, the creditors can liquidate the firm among themselves through a composition, ${ }^{19}$ a general assignment, ${ }^{20}$ or a bulk transfer. ${ }^{21}$ These out-ofcourt settlements are usually preferred to their Bankruptcy Act counterparts, the Chapter XI arrangement and the straight bankruptcy liquidation, since they are cheaper and less stigmatizing. ${ }^{22}$

16. The formal conditions for the sole creditor's responses depend on the relationship between the firm's prospects and the costs of bankruptcy liquidation. See Van Horne, Optimal Initiation of Bankruptcy Proceedings by Debt Holders, 31 J. Finance 897 (1976). Although Van Horne refers to "debt holders," he treats them as a single decisionmaking unit. See, e.g., id. at 907 . In reality, this decision is based on market, economic, and cashflow analyses and the creditor's own evaluation of management. See Stierhoff, Does $I n$ solvency Mean Bankruptcy?, Credit and Financial Management, Mar. 1976, at 14, 15.

17. The common law composition is a mutual reduction of debts or extension of maturities; it is employed to liquidate a failing business or to enable the business to survive. G. GLEN, supra note 12, $\$ 85$; Nadler, "Methodes Preventives de Faillite": An American Report on "Proceedings Short of Bankruptcy", 9 MERCER L. Rev. 240, 247-48 (1958). Since it is a contractual device, G. GLENN, supra note $12, \S 89$, the composition cannot bind nonassenting creditors. J. MAcLACHLAN, supra note 8 , at 371 . The composition bars suit by assenting creditors on the underlying debts, G. GLENN, supra note 12 , $\$ 90$, at 152 , but a secret voluntary preference by the debtor to one of the composing creditors renders the agreement voidable by the other creditors, id. $\$ 96$. They may choose not to void the composition, however, for the same reason they originally entered the original composition agreement-a higher return from an ongoing business. Since the nonpreferred creditors have no action in contract against the preferred creditor, id. $\$ \$ 99-102$, neither does the trustee in bankruptcy, id. $\$ 103$, because his rights derive from theirs, Bankrutpcy Act $\$ 70(c), 11$ U.S.C. $\$ 110(c)(1970)$.

18. See, e.g., All Was Not Well in the War Room, Fontune, Nov. 1975, at 25 (attempted work-out of W.T. Grant, involving subordination of $\$ 300$ million of bank debt to trade credit); House Hearings, supra note 5, pt. 1, at 436.37 (Patrick A. Murphy, Esq.). See generally J. Moore \& W. Phillirs, Debtors' ANd CReditors' Rights 3-1 to 3-12 (4th ed. 1975).

19. G. GLeNN, supra note $12, \S 85$; Nadler, supra note 17 , at 247.

20. G. GlenN, supra note $12, \$ 105$; Hanna, Contemporary Utility of General Assign. ments, 35 VA. L. REv. 539, 539-40 (1949) (general assignment is voluntary transfer by debtor of all his property to liquidating trustee; rarely occurs without consultation with creditors); Nadler, supra note 17, at 242-44.

21. Nadler, supra note 17 , at 245-47.

22. E.g., Commission RePort, supra note 4, pt. I, at 47; House Hearings, supra note 5, pt. 1, at 479 (colloquy between Patrick A. Murphy, Esq., and Rep. Butler) ("no question that an extra[-]judicial settlement of all differences is to be preferred"). 
Each individual creditor, however, has a third group of options, which can undermine the optimality of the decision to liquidate or support in the multiple creditor case. Law and business custom give each creditor a number of individual remedies for the persuasion or coercion of the unvilling but solvent debtor. ${ }^{23}$ A creditor who chooses to look only after his own interests may dun, ${ }^{24}$ threaten, litigate and levy after judgment, or take possession pursuant to a security interest. ${ }^{25} \mathrm{~A}$ creditor's special business or personal relationship with the debtor may give him the leverage necessary to obtain a voluntary preferential payment. ${ }^{20}$ If allowed, such preferences may harm the firm and its remaining creditors, both by increasing the likelihood of failure and by reducing the assets available for proportional distribution to the creditors in case of failure. Transfers of cash or other assets reduce the firm's ability to function, ${ }^{27}$ and transfers of security interests reduce the firm's ability to obtain new financing. ${ }^{28}$ Attachment and levy publicize the debtor's plight and may force an immediate voluntary petition ${ }^{29}$ by causing a "run" on the debtor..$^{30}$

Whether liquidation or support is the appropriate response, unilateral actions by creditors may produce results inferior to the solecreditor ideal. When liquidation is called for, the creditor pursuing an individual remedy may receive a disproportionate share of his debt. ${ }^{31}$ When support would maximize the total return to creditors, a preference is likely to decrease the firm's chances for survival, thereby frustratng both the maximization and the equality goals. In such cases, the

23. See G. GlenN, supra note 12, $\$ \$ 4$, 5; J. MacLachlan, supra note 8 , at $3 \cdot 4,10$.

24. See T. Beckman \& R. Foster, Credits and Collections: Management and Theory 201 (8th ed. 1969).

25. U.C.C. $\$ 9-503$ (secured party's right to take possession after default); see Zweibel, Work-Out Problems and Solutions, BaNkers MAgazine, Spring 1976, at 87, 88-89 (discussing advantages of practice).

26. See, e.g., De Stefano v. American Chocolate Almond Co., 107 N.J. Eq. 156, 158 (Ch. 1930) (controlling sharcholder caused corporation to repay note he had endorsed); J. MaclacillaN, stipra note 8, at 284; Interview with Louis Rosenberg, Esq., in New York City (Nov. 22, 1977), at $7-8$ (transcript on file with Yale Law Journal) [hereinafter cited as Rosenberg Interview].

27. See Jensen v. State Bank, 518 F.2d 1, 5 (8th Cir. 1975) (bank's "harsh unilateral action" in setting off firm's deposits against debt owed bank may have contributed to firm's bankruptcy); P. Hunt, C. Williams \& G. Donaldoson, Basic Business Finance 9-12 (4th ed. 197I). See generally id. at 21-103.

28. A security interest in existing assets is a common precondition for new financing when a firm is in a precarious state. See, e.g., In re Cushman Bakery, 526 F.2d 23 (Ist Cir. 1975), cert. denied, 425 U.S. 937 (1976); Stierhoff, supra note 10, at 84-85.

29. Rosenberg Interview, supra note 26 , at $2-4$.

30. Zweibel, supra note 25, at 89; 28 U. PiTt. L. Rev. 344, 350 (1966).

31. The creditor who, in pursuing an individual remedy, publicly provides proof of the debtor's plight does serve the useful function of informing other creditors. Secret, voluntary transfers compromise equality with no saving grace. Rosenberg Interview, supra note 26, at 18. 
preferred creditor gains more than enough at the expense of the other creditors to offset any losses the preferred creditor incurs through the damage it does to its customer. ${ }^{32}$

\section{B. The Function of Preference Law During Insolvency}

Preference law is an apt means of encouraging cooperative rather than individual approaches to the debtor's problems. ${ }^{33}$ Noncooperative responses may be voidable preferences under certain circumstances. ${ }^{34}$ If preference law enforced absolute equality in liquidation, individual approaches would be discouraged because they would not maximize the total value of the firm, on which the return to each creditor would then depend. Unilateral action would neither enrich the defector nor harm the loyal creditor in liquidation, but if the firm survived the defector would risk losing business as a result of its earlier intransigence. The supporting creditor, by contrast, might gain business if the firm survived-as a reward for its loyalty-and yet be no worse off than the defector in liquidation. When continued operations would erode the firm's expected value, well-informed, rational creditors would press for liquidation. These demands would occur under the same circumstances that would cause a sole creditor to press for liquidation. Since creditors could further their individual interests only by maximizing the expected return to their class, an especially well-informed or powerful creditor, be it a bank, a large supplier, or a small creditor with special

32. The fear that others may obtain payment first also leads to premature attempts to obtain payment. Restrictions on individual behavior are thus needed to maximize the total return to the class. See G. Dworkin, Paternalism, in Moral Proulems in Medicine 185, 189 (S. Gorovitz et al. eds. 1976):

There are restrictions which are in the interests of a class of persons taken collectively, but are such that the immediate interest of each individual is furthered by his violating the rule when others adhere to it. In such cases the individuals involved may need the use of compulsion, to give effect to their collective judgment of their own interest....

See R. Luce \& H. Raiffa, Games and Decisions 94-102 (1957); A. Rapoport \& A. Chammah, Prisoner's Dilemma viii-ix (1965) (discussion of nonzero-sum games, especially the Prisoner's Dilemma).

33. McLaughlin, Defining a Preference in Bankruptcy, 60 HARv. L. REv. 233, 235 (1946):

Adjudication in bankruptcy is commonly reserved for cases where slender assets have precluded compositions or other satisfactory arrangements with creditors. The terms upon which such settlements can be made are substantially affected by the extent of the law of preference. A creditor who knows that he can be compelled in bankruptcy to disgorge undue advantage is in a much better mood to enter into reasomable arrangements than the creditor who feels, not without reason, that he must grab the debtor's assets to prevent others getting them first.

Accord, House Hearings, supra note 5, pt. 3, at 1668 (Richard Kaufman, Nat'l Ass'n of Credit Management) (elimination of preference law would prejudice out-of-court settlements); Coogan Testimony, supra note 10, at 433.

34. Bankruptcy Act $\$ 1(30)$, 11 U.S.C. $\$ 1(30)$ (1970) (broad definition of "transfer"). 
personal knowledge, would no longer be able to exploit its position for individual gain at the possible expense of the class as a whole..$^{35}$ Such creditors would have to act in the interest of all members of their class to maximize their own return. Although differences in judgment and information would persist, all creditors would be attempting to approximate the same decision, that of the sole creditor.

If preference law fails to preserve absolute equality in liquidation, those creditors who are aware of this failure ${ }^{3 t}$ will compete for position during insolvency rather than cooperating fully in an attempt to maximize the value of the firm. ${ }^{37}$ This is in fact the case under both existing preference law and H.R. 8200.

\section{The Inadequacy of Existing Preference Law}

Both the present section $60^{38}$ and the preference provisions of H.R. $8200^{30}$ fall short of the full-deterrence ideal. Both hold out to nervous creditors the hope that a contemplated transfer will not be deemed preferential, and both make it clear to creditors that the most premature transfers-those that are taken the earliest-will be the most protected. The provisions that undermine the deterrent effect are the balance-sheet insolvency test, ${ }^{40}$ the fixed time-limit rules ${ }^{41}$ and, under section 60 , the rule that the trustee must show that the creditor had reasonable cause to believe that the debtor was insolvent at the time of

35. See Rosenberg Interview, supra note 26 , at 8 .

36. Creditors are aware of the preference provisions, which shape their actions during their debtors' insolvencies. Coogan Testimony, supra note 10, at 395; see Zweibel, supra note 25 , at 88.89 .

37. E.g., House Hearings, supra note 5, pt. 1, at 479-80, 503-04 (Patrick A. Murphy, Esq.); Bankruplcy Reform Acl: Hearings on S. 235 and S. 236 Before the Subcomm. on Improvements in Judicial Machinery of the Senate Comm. on the Judiciary, 94th Cong., Ist Sess. 397 (1975) (Benjamin Weintraub \& Michael J. Cramer, Esqs.) [hereinafter cited as Weintraub \& Cramer]; Rosenberg Interview, supra note 26, at 18; see Zweibel, supra note 25 , at 88.94.

38. 11 U.S.C. $\$ 96(1970)$.

39. H.R. $8200 \$ 547$.

40. Bankruptcy Act $\$ 1(19), 11$ U.S.C. $\$ 1(19)(1970)$ :

I person shall be deemed insolvent within the provisions of this . Ict whenever the aggregate of his property, exclusive of any property which he may have conveyed, transferred, concealed, removed, or permitted to be concealed or removed, with intent to defraud, hinder, or delay his creditors, shall not at a fair valuation be sufficient in amount to pay his debts . . . .

Accord, H.R. $8200 \$ 101(25)$. See generally $3 \mathrm{~J}$. Mooke \& L. Kix(, supra note 3, 60.30. 41. Bankruptcy .Ict $\$ 60(a), 11$ U.S.C. $\$ 96(a)$ (1970) (preferences restricted to transfers by the bankrupt occurring "within four months before the filing by or against him of the petition"); H.R. $8200 \$ 547(\mathrm{~b})(4)(\mathrm{A})$ ("on or within 90 days before the date of the filing of the petition"). 
the transfer. ${ }^{42}$ H.R. 8200 further undermines the deterrent effect of preference law by exempting from preference attack payments made on short-term trade credits. ${ }^{43}$

\section{A. Balance-Sheet Insolvency}

A financial analyst can often conclude that a firm is in serious difficulty before the firm is actually balance-sheet insolvent. ${ }^{4 *} \mathrm{~A}$ commercial bank, moreover, can continuously monitor a firm's cash balances on deposit. ${ }^{4 \overline{5}}$ Since any transfer made during the period before balance-sheet insolvency is immune from preference attack, early defection is rewarded..$^{46}$

Under present law, the trustee must prove that the debtor was insolvent at the time of the transfer. ${ }^{47}$ Since the records of many bankrupts are confused and inadequate, the burden of proving insolvency has defeated many preference actions. ${ }^{\$ 8}$ For preferences taken within the three-month period preceding the filing of a petition, H.R. 8200 shifts the burden of going forward on the solvency question to the defendant. The ultimate burden of proof, however, would remain with the trustee. ${ }^{40}$ This change reduces the probability that a given transfer will survive on solvency grounds.

An additional problem arises when a Chapter XI arrangement rather than a bankruptcy liquidation is in the offing. Because an arrangement petition may be filed while the debtor firm is not balance-sheet insolvent,,$^{50}$ preferences taken on the very eve of the filing of a Chapter

42. Bankruptcy Act $\S 60(\mathrm{~b}), 11$ U.S.C. $\$ 96(\mathrm{~b})$ (1970). This provision is not present in H.R. 8200. See CoMmission REPORT, supra note 4, pt. I, at 20 (recommending elimination of provision).

43. H.R. $8200 \S 547$ (c)(2).

44. Discriminant analysis has shown that financial ratios predict bankruptcy accurately up to three years in advance, Deakin, $A$ Discriminant Analysis of Predictors of Business Failure, $10 \mathrm{~J}$. AccountiNg RESEARCH 167, 178 (1972), and a behavioral study using the same data has shown that loan officers can also predict bankruptcy this long in advance, Libby, Accounting Ratios and the Prediction of Failure: Some Behavioral Evidence, $13 \mathrm{~J}$. Accounting ResedRch 150, 160 (1975).

45. See Rosenberg Interview, supra note 26 , at 8 .

46. The balance-sheet test of insolvency was originally intended to discourage the filing of premature petitions, and this has had the "regrettable effect of increasing the inequality among creditors through the resulting reduction of the area of recoverable preferences." 1 J. Moore \& L. KiNG, supra note 3, 1.19, at 101-03. See id. at 101-03 nn.18 \& 22.

47. 3 J. MOORE \&. L. King, supra note 3, If 60.30, at 893.

48. Commission REPORT, supra note 4, pt. I, at 19; House Hearings, supra note 5, pt. 3, at 1 179 (Robert J. Grimmig, Am. Bankers Ass'n Bankruptcy Task Force) (bankrupts' records "chaotic").

49. H.R. 8200 \$ 547(f); H.R. Rer. No. 95-595, 95th Cong., Ist Sess. 375 (1977) (discussing $\S 547$ (f) in light of FED. R. Evid. 301).

50. An arrangement petition may be filed when the debtor is "unable to pay his debts as they mature," Bankruptcy Act $\$ 323,11$ U.S.C. $\$ 723$ (1970), a standard generally less stringent than balance-sheet insolvency, see pp. 1460-61 infra. 
XI petition may be invulnerable. In such cases, the race of the diligent continues until the moment the petition is filed. This situation is anathema to Chapter XI, whose rehabilitative purpose is frustrated unless the firm maintains uninterrupted control over its operating assets. 51

\section{B. The Time-Limit Rules}

The four-month rule "reduce[s] the preference to a sporting proposition." will be filed, they cannot be certain that any transfer will be voidable. Other things being equal, a creditor is well advised to defect as soon as possible. Once the transfer has been made, the creditor has an incentive to postpone the petition by keeping both the transfer and the debtor's plight secret at a time when candor and cooperation are most needed. The rule invites creditors to keep debtors out of bankruptcy for the statutory period and then to abandon them summarily. ${ }^{53}$ This may result in a wasting of assets due to mismanagement during this period, 54 or even in an unnecessary bankruptcy. Cooperation might have saved the firm had all the facts been known publicly and had all the creditors jointly cooperated in the firm's support.

By shortening the preference period to three months for noninsider preferences, ${ }^{55}$ H.R. 8200 increases the probability that a given preference will survive bankruptcy. Creditors with influence over the debtor, once they have been preferred, naturally seek to delay bankruptcy for four months. ${ }^{56}$ The difficulty of this effort increases with time because knowledge of the debtor's plight spreads and the patience of the other creditors wears thin. ${ }^{57}$ H.R. 8200 thus eliminates the need

51. Hertzberg, A Survey of Chapter XI With a Side Trip Through Chapter X, 77 CoM. L.J. 86, 86 (1972).

52. 2 G. Glenn, Fraudulent Conveyances and Preferences $\$ 384$, at 664 (1940).

53. House Hearings, supra note 5, pt. 3, at 1669 (Richard Kaufman, Nat'l Ass'n of Credit Management) (quoting former Bankruptcy Judge Daniel R. Cowans); Rosenberg Interview, supra note 26, at 8; see Zweibel, supra note 25, at 88 .

54. See 44 YALE L.J. 109, 119 (1934). Allowing an incompetently managed firm to survive harms both creditors and the general cconomy through a misallocation of resources. N. Buchanan, The Economics of Corporate ENTERPRise 393-94 (1940).

55. H.R. $8200 \S 547(\mathrm{~b})(4)(\mathrm{A})$.

For insider preferences, H.R. 8200 establishes a special period between 90 days and one year before the petition is filed. During this period transfers may be attacked, H.R. 8200 $\$ 547(\mathrm{~b})(\mathrm{A})(\mathrm{B})$, but only subject to the defenses available under existing law, see p. 1456 supra; p. 1458 infra. This period may be long enough to dampen hopes of riding out the preference period. Nevertheless, the availability of other defenses might still lead an insider to defect.

56. House Hearings, supra note 5, pt. 3, at 1669 (Richard Kaufman, Nat'l Ass'n of Credit Management); Rosenberg Interview, supra note 26, at 8.

57. House Hearings, supra note 5, pt. 3, at 1669 (Richard Kaufman, Nat'l Ass'n of Credit Management). 
to delay bankruptcy for the fourth (and most difficult) month and thus may be expected to increase disproportionately the number of successful defections.

\section{The "Reasonable Cause to Believe" Requirement}

Section $60(\mathrm{~b})$ requires that in order to avoid a preference the trustee must prove that the transferee had reasonable cause to believe that the debtor was insolvent at the time of the transfer. ${ }^{58}$ Primarily because of this requirement, the "vast majority of preferential transfers are never recovered."59 By abolishing this requirement within its three-month time period, ${ }^{60}$ H.R. 8200 increases the probability that a given transfer will be voidable.

\section{The H.R. 8200 Trade Credit Loophole}

Section 547 (c)(2) exempts from preference attack payments made in the ordinary course of business on account of debts incurred less than forty-five days before the payment. ${ }^{61}$ Although trade creditors are now considered to be the group most willing to cooperate in out-of-court settlements, ${ }^{62}$ this provision would encourage them to compel prompt payment at a time when flexibility in credit terms might maximize the firm's value. ${ }^{63}$ Once a timely payment is received, moreover, it is invulnerable to preference attack, and hence bankruptcy would no longer serve as a threat to force settlement with respect to such creditors. ${ }^{0.1}$ Both with respect to trade debts incurred within forty-five days and not yet paid, and with respect to debts paid within that period, this provision would undermine the goal of creditor control.

At the time the transfer is initially contemplated, creditors can rarely be certain that a particular transfer will be a voidable preference. As a result, the deterrent effect of preference law is minimal. ${ }^{65} \mathrm{~A}$

58. 11 U.S.C. $\$ 96(b)$ (1970). See generally 3 J. MOORE \& L. KING, supra note 3, If $60.54-.56$.

59. Cyr, Setting the Record Straight For A Comprehensive Revision of the Bankruptcy Act of 1898, 49 AM. BANkr. L.J. 99, 166 (1975).

60. Compare H.R. $8200 \$ 547(\mathrm{~b})(4)(\mathrm{A})$ with id. $\$ 547(\mathrm{~b})(4)(\mathrm{B})$. Accord, Commission REPORT, supra note 4, pt. 1, at 201.

61. H.R. $8200 \S 547(\mathrm{c})(2)$.

62. P. Hunt, C. Williams \& G. Donaldson, supra note 27, at 569.

63. See pp. $1451-55$ supra.

64. House Hearings, supra note 5, pt. 3, at 1669-70 (Richard Kaufman, Nat'l Ass'n of Credit Management) ("one of the most serious ramifications . . . is to jeopardize the ability of the majority of creditors ... to reason with a single creditor threatening attachment").

65. Zweibel, supra note 25, at 88-94; Weintraub \& Cramer, supra note 37, at 397; House Hearings, supra note 5, pt. 1, at 479.80 (Patrick .1. Murphy, Esq.). 
common and reasonable rule of thumb is to take the transfer and hope that in the event of preference attack some defense will be found.66 Even under H.R. 8200, diligent haste in pursuit of individual remedies remains the best way to ensure that a preference will survive under both the insolvency and the time-limit rules.

\section{Maximization and Strict Equality: A New Preference Rule}

This Part proposes and defends a preference provision that could both maintain intercreditor equality and warn creditors before they take their preferences that they have nothing to gain from seeking preferences at the expense of a cooperative solution. ${ }^{67}$ Under the proposed rule, transfers would be vulnerable whenever a firm is generally unable to pay its maturing obligations. This insolvency standard-known as "equitable insolvency" 68 -would put creditors on notice, before the temptation to defect becomes acute, that preferences will be voided in bankruptcy. The time-limit rules would be replaced by an affirmative defense protecting preferences given during insolvencies unrelated to the one that culminated in bankruptcy.

The proposed rule ${ }^{69}$ rould optimize creditor behavior during the

66. Rosenberg Interview, supra note 26, at 18; see Zweibel, supra note 25, at 88-89. A creditor who knows his debtor is insolvent and has the opportunity to take a transfer "should take it, of course, and hope that [the debtor] rides out the next four months." Lecture by Grant Gilmore, Yale Law School (Mar. 8, 1978).

67. It might be objected that the effective elimination of the possibility of securing an antecedent debt during insolvency would result in more bankruptcies, since lenders unwilling to continue their support on an unsecured basis, see Damarin \& Co. v. Huron Iron Co., 47 Ohio St. 581, 590, 26 N.E. 37, 40 (1890) (embarrassed company's right to grant a security interest where necessary to forestall creditor action), would then have no option but to file a petition against the debtor. But where a sophisticated creditor concludes that bankruptcy is preferable to support unless he is preferred over other creditors, bankruptcy is the optimal result. See pp. 1451-54 supra.

68. Equitable insolvency, the inability to meet one's obligations as they become due in the ordinary course of business, relates to the firm's condition over a period of time, in contrast to the static balance sheet test. $1 \mathrm{~J}$. Moore \& L. KiNG, supra note $3,91.19$, at 98-99. It "conceives of insolvency as a status or condition, to be differentiated from mere symptomatic occurrences such as chronic defaults in current payments." Id. at 99. This conception of insolvency, "more ancient than bookkeeping itself," G. GleNN, supra note $12, \$ 13$, at 22 , is widely used outside of bankruptcy, $i d$. $\$ 13$, and determines eligibility for Chapter XI arrangements as weIl, Bankruptcy Act $\$ 323,11$ U.S.C. $\$ 723$ (1970).

69. The proposed preference statute, drafted in the language of $\$ 60$, might read as follows:

a. A preference is a transfer, as defined in this Act, of any of the property of the debtor to or for the benefit of a creditor for or on account of an antecedent debt made or suffered by such debtor while insolvent or unable to pay his debts as they matured in the ordinary course of business, the effect of which transfer will be to enable such creditor to obtain a greater percentage of his debt than some other creditor of the same class.

b. Any such preference may be avoided by the trustee, provided that it shall be a defense that the insolvency during which the transfer occurred was not directly related to the ultimate bankruptcy. 
work-out period and would realize the goal of intercreditor equality more fully than does existing law. In addition, the proposed rule may even have salutary effects on the original lending agreements made during the firm's period of financial health.

Under this rule, creditors of an insolvent debtor would have no incentive to pressure the debtor for preferential transfers. Since none could gain advantage, each could rest assured that no other creditor was draining the firm. Meanwhile, the firm's business could continue, perhaps with all supplies paid for in cash and all new borrowings fully secured. So long as such operations hold out the hope of increasing the firm's net worth, the creditors-their rights protected vis-à-vis one another-would continue to opt for support rather than for immediate liquidation.

\section{A. The Equitable Insolvency Test}

The equitable insolvency test is widely employed and so presents few novelties in its application. ${ }^{70}$ In particular cases, the policy behind the rule, that of promoting cooperative behavior, could guide a court. ${ }^{71}$

Given the apparent ability of sophisticated lenders to detect trouble in advance, ${ }^{72}$ no definition of "insolvency" could cover all situations in which a creditor becomes concerned about its debt. Nor would such a definition be desirable, for so long as the debtor is generally able to pay its debts there is no objection to its doing so. It is only when favoring one creditor begins to harm others that the interest in deterring preferences arises.

The inability to pay matured obligations is a far more common occurrence than either balance-sheet insolvency or bankruptcy itself; in most cases it occurs before balance-sheet insolvency. ${ }^{73}$ The new standard, therefore, would greatly increase the number of cases in which

70. See, e.g., G. GLEN, supra note 12, $\$$ 12-13; Krause, What Constitutes Insolvency, in Proceedings of the New York University Twenty-Seventh ANnual Institute on Federal TAxation 1081, 1081-83 (H. Sellin ed. 1969).

71. Suppose, for example, a firm entered into a composition agreement with its creditors in month one that aimed at an eventual recovery by providing for scaled-down payments over time. In month three, the firm secretly paid a party to the composition in full. In the month six bankruptcy proceeding, the policy of the statute clearly demands that the preference be recoverable, even if the firm was making the payments to others required by the composition. Such a result may be reached by recalling that the coinposition does not discharge the underlying claims until it has been paid in full, G. GLENN, supra note 12, $\$ \$ 99-102$, and thus is merely an extraordinary and contingent stay of obligations that have already matured in the ordinary course of business. The firm may therefore be considered insolvent as of month three.

72. See note 44 supra.

73. J. MAcLAchlaN, supra note 8 , at 12 ; see Krause, supra note 70 , at 1085 (Congress aware of broad impact that choice of equity standard would have). 
the creditor would comprehend the need to seek a preference only when it was too late, after insolvency had already occurred. Even a creditor aware of the debtor's condition at all times may choose not to apply pressure on the debtor preemptively, before equitable insolvency occurs. Business firms, especially smaller firms, are so often in financial difficulties short of equitable insolvency-usually without a liquidation resulting ${ }^{74}$-that a creditor inclined to defect regularly in such situations would soon suffer a loss of business. ${ }^{75}$ The benefits of early defection (which accrue only in the event of bankruptcy) outweigh the fruits of support (which are realized if the firm survives) only when the probability of bankruptcy is high; that probability will not be high in most cases as long as the firm is meeting all of its obligations promptly.

Under existing law a creditor can almost never be sure that a contemplated transfer will be held voidable in bankruptcy. This uncertainty is due both to the four-month rule and to the balance-sheet insolvency test. Unlike balance-sheet insolvency, equitable insolvency is readily ascertainable by all types of creditors. ${ }^{76}$ The failure of prompt payment is obvious to a creditor, and the extent of a default can be ascertained informally or through trade organizations and publications. ${ }^{77}$ More creditors would therefore be on notice that it is useless to seek preferential treatment, and the deterrent effect of the law would be enhanced..$^{8}$

Finally, the equitable insolvency standard brings the preference provision into line with Chapter XI's eligibility standard: ${ }^{79}$ it would no longer be possible for a firm to be "solvent" for preference purposes, and yet qualify for Chapter XI. Preferences on the eve of a Chapter XI petition would be as fully deterred as their eve-of-bankruptcy counterparts.

\section{B. The Relatedness Proviso}

Neither equality nor maximization would be served by avoidance of transfers occurring outside "the penumbra of the financial eclipse that

74. See Small Business, Bus. WEEk, June 30, 1975, at 96; Coogan Testimony, supra note 10 , at 395 .

75. See T. BECKMAN \& R. FosTer, supra note 24, at 519-25.

76. P. Hunt, C. Williais \& G. Donaldson, supra note 27, at 563-64.

77. T. BEckMan \& R. Foster, supra note 24, at 386-91; Rosenberg Interview, supra note 26 , at $2-3$.

78. The deterrent effect of a legal rule depends in large part on awareness of the rule on the part of those to be deterred. See, e.g., F. Zimring \& G. Hawkins, Deterrence $141-42$ (1973) (criminal law).

79. Bankruptcy Act $\$ 329,11$ U.S.C. $\$ 723$ (1970) (contents of petition); see p. 1456 supra. 
finally overtook" the bankrupt, ${ }^{80}$ but this interest must be served without compromise to the statute's deterrent effect.

Unlike the fixed time-limit rules it would replace, the relatedness proviso would not invite creditors to defect prematurely and then hope to be able to interpose the time-limit defense. The relatedness defense would apply only if a substantial period of solvency intervened between the transfer and the bankruptcy. During this period the debt would have been payable, by definition, in the ordinary course of business. The relatedness proviso protects only preferences that the defector did not need to exact at all. The destructive effect of the preferential transfer on the firm's prospects and the loss of goodwill resulting from pressuring the debtor combine to make defection in reliance on the relatedness proviso irrational and self-destructive.

The relatedness proviso would be more difficult for judges to apply than the mechanical four-month rule it would replace. Only by sacrificing the after-the-fact certainty of the four-month rule can the beforethe-fact certainty necessary for effective deterrence be gained. The following examples demonstrate the workability of the proviso and illustrate its meaning.

Consider a firm whose normal operating cycle-raw materials to finished goods to receivables to cash-is four months. During a liquidity crisis in year $A$, the firm preferred certain creditors but was unable to pay most other creditors. The firm recovered its solvency later that year and until month one of year $C$ it did not again fall behind in payments due. Bankruptcy followed in month six. The intervening period of solvency-year $B$-was much longer than the firm's cycle and was clearly long enough for the earlier insolvency to be deemed unrelated.

As under existing law, however, intervening solvency would not constitute a complete and automatic defense. ${ }^{81}$ When solvency results from an extraordinary transaction rather than a true business recovery, the earlier insolvency should be deemed related. A comparison of the length of the solvency with the firm's operating cycle should be probative of this fact.

Suppose, for example, the same firm factored a sufficient amount of accounts receivable in month four to pay its debts due for that month, but lapsed into equitable insolvency again in month five. Assuming balance-sheet solvency during month four, the creditors paid during

80. 2 G. GLENN, supra note $52, \S 379$.

81. $3 \mathrm{~J}$. MOORE \& L. KiNG, supra note $3, \uparrow 60.31$, at $895 \mathrm{n} .5$ ("Where a business is of a nature that fluctuates rapidly, the proof of later insolvency is of little weight" in determining whether business was insolvent when transfer was made.) 
that month would not be considered preferred. A repayment of a term loan in month three would still be voidable, however, since the insolvency beginning in month one was related to the ultimate bankruptcy.

Application of the proviso would also require examination of the firm's business practices. Consider another firm that for years had been a habitual slow payer, regularly waiting for one overdue notice before paying. In month one the firm began to be two, then three, months late instead of its usual one month. In the bankruptcy that follows in month six, transfers made before month one should not be deemed preferential since the ordinary course of this firm's business included a certain degree of lateness.

\section{The Distributional Effect of the Proposed Rule}

Greater equality in liquidation can be attained by discouraging and avoiding preferences. This redistributes wealth to the estate from the sophisticated or influential creditors that now succeed in retaining preferences. The estate can then distribute its greater wealth to the unsophisticated and sophisticated creditors according to the sizes of their claims. The ultimate net redistribution is impossible to predict since all the creditors will, in turn, pass on some of these costs and benefits to their customers and absorb the remainder in their own profit and loss. ${ }^{82}$ Because of the effect of the rule on creditor behavior during insolvency, however, the total costs of insolvency would be reduced. ${ }^{83}$

82. Even under perfect competition, computation of the degree of passing on is complex and requires calculation of elasticities of supply and demand. Shaefer, Passing-On Theory in Antitrust Treble Damage Actions: An Economic and Legal Analysis, 16 WM. \& MARY L. REv. 883, 887-900 (1975).

To the extent that costs and benefits are passed on, redistributive effects should roughly cancel since most business units and consumers deal with both the sophisticated and the unsophisticated. To the extent that costs are not passed on, there would be a redistribution from sophisticated creditors (e.g., banks) to the less sophisticated (e.g., suppliers of goods), a factor that would determine the interest of each group in the passage of such a statute. Compare House Hearings, supra note 5, pt. 3, at 1749-50 (Robert Grimmig, American Bankers Ass'n) with id. at 1668 (Richard Kaufman, Nat'l Ass'n of Credit Management) (bankers support preference scienter requirement, trade creditors oppose).

83. If, for some reason, sophisticated creditors are to be subsidized or interest rates artificially reduced in preference to other prices, means should be employed that accomplish the desired transfer without deadweight losses. C. IVILcox, Public Policies Toward Business 786-806 (4th ed. 1971). Interest rates are best controlled by the open market policies of the Federal Reserve. D. Jacobs, L. Farwell \& E. Neave, Financial Institutions 570-71 (5th ed. 1972). 


\section{The Effect on the Lending Decision}

The total amount of bank credit loaned to business firms may be directly affected by changes in preference law. Some borrowers would borrow less at higher interest rates, and lenders might be unwilling to lend as much, or on the same terms, as they do under existing law. When a loan is made the possibility of bankruptcy does not loom large, as it does in work-out situations. ${ }^{s t}$ Accordingly, the preference provisions cannot be expected to play a major role in shaping creditor behavior at this earlier stage. But to the extent that creditors realize in advance that preferential treatment will later be impossible to obtain, the proposed rule's effects on the decision to lend would be salutary.

The proposed rule would suppress loans made in reliance on the possibility of future preferential repayment or security. ${ }^{85}$ Loans to more creditworthy firms would be unaffected by the change in the preference rule; competitive forces would continue to guarantee favorable terms to nonmarginal firms. ${ }^{86}$ For marginal firms, the creditors are in a position analogous to that of the holders of secret equitable liens. ${ }^{87}$ Both credit arrangements lead to the overextension of credit by creating the illusion that the debtor has unencumbered assets available for pro rata distribution in the event of default. ${ }^{s 8}$ Indeed, several creditors may have lent in implicit reliance on future preference with respect to the same assets. When the firm begins to encounter difficulties, these unsecured assets provide the temptation to defect that leads to a destructive race of diligence to obtain preferences.

The decision to lend in such cases is based on an inaccurate assumption, since not all creditors can be preferred. The effect of the proposed

84. Provisions for loan Iosses of commercial banks typically average less than one-third of one percent of outstanding loans. BANK AdMINistration INSTITUTE, The 1975 BAI INDEX OF BANK Performance (1976) (unpaginated).

85. If there is a public interest in making credit available on a subsidized basis to certain marginal borrowers, credit can be made available directly. See, e.g., P. HuNr, C. Williams \& G. Donaldson, supra note 27, at 526-34 (Small Business Administration loan programs). Any "subsidy" created by the present system is, in effect, a redistribution to marginal firms from the less sophisticated creditors who lend on the illusion of an unsecured asset pool.

86. See D. Hodgman, Commercial Bank Loan and Investment Policy 28, 36-37, 97112 , 158-59 (1963) (although competition in banking is hardly "cut-throat," neither is it oligopolistic); P. Hunt, C. Williams \& G. Donaldson, supra note 27, at 236 (competitive pressures may permit borrower to wring concessions from bank lenders).

87. Now known as holders of unperfected security interests, these creditors regularly escaped preference attack on the ground that their liens, although filed on the eve of bankruptcy, related back to the date of the original transfer. J. HonNold, Cases \&: Materials on the Law of Sales and Sales Financing 571-74 (4th ed. 1976).

88. The prevention of general overextension of credit has been considered a major function of preference law. J. MAcLachlan, supra note 8 , at 283 . Indeed, the passage of the first national preference statute was predicated on this idea. Id. at 284. 
rule would be to discourage the overextension of credit in marginal cases by encouraging lenders to take security interests at the time the loan is made. The security interest would be publicly filed; ${ }^{89}$ subsequent credit need not be provided in the vain hope that the assets in question would in fact be available to unsecured creditors in bankruptcy. This may seem a harsh result at first: if lenders secure fully at the time of each loan, fewer unencumbered assets would remain for other creditors. The loss of unsecured assets is quite illusory, however, for without a fully deterrent preference policy, those assets would quite likely have been pledged to secure one loan or another by the time of bankruptcy. ${ }^{90}$

\section{Conclusion}

Without a means of controlling creditors' pursuit of preferential transfers, the economic incentives presented to creditors of a troubled firm can lead to a mutually destructive "race of diligence." Existing preference law fails to prevent this race. Preference law should therefore be modified to eliminate creditors' incentives to defect prematurely during the work-out period. Lacking the option of reaching a "separate peace" with the debtor, the creditor will find himself injured by any harm he does to the firm through obtaining a preference. Instead, the energies of creditors with special knowledge or special analytic capabilities would be turned toward preserving the greatest total value for the firm, an endeavor that would incidentally protect other creditors as well. Creditors would find it much easier to sit down together and pool their knowledge and judgments to arrive at the best solution. The temptation to defect singly and the fear that others may do so would no longer frustrate these efforts; composing creditors would be able to force a recalcitrant creditor to disgorge its preference more effectively than they can under present law. The life of the firm would not be prolonged in order to run out the four-month period on some transfer, nor would costly Chapter proceedings or wasteful liquidations in bankruptcy be precipitated unnecessarily. In this way, the skills and knowledge of sophisticated and favored lenders can be turned from the pursuit of individual gain toward cooperation for the benefit of all.

89. U.C.C. $\$ 9-302$.

90. 3 J. MoORE \& L. KING, supra note $3, \$ 60.01$, at 744 . 